THE FINE STRUCTURE OF THE MESOGLOEA OF THE COLUMN OF PACHYCERIANTHUS FIMBRIATUS (ANTHOZOA)

$\operatorname{AUTHOR}(\mathrm{S})$ :

Arai, Mary Needler; Karakashian, Stephen

CITATION:

Arai, Mary Needler ...[et al]. THE FINE STRUCTURE OF THE MESOGLOEA OF THE COLUMN OF PACHYCERIANTHUS FIMBRIATUS (ANTHOZOA). PUBLICATIONS OF THE SETO MARINE BIOLOGICAL LABORATORY 1973, 20: 719-729

ISSUE DATE:

1973-12-19

URL:

http://hdl.handle.net/2433/175747

RIGHT: 


\title{
THE FINE STRUCTURE OF THE MESOGLOEA OF THE COLUMN OF PACHYCERIANTHUS FIMBRIATUS (ANTHOZOA)
}

\author{
Mary NeEdler ARAI and Stephen KARAKASHIAN ${ }^{1)}$ \\ Department of Biology, the University of Calgary, Calgary, Alberta, Canada \\ and Department of Biology, Rice University, Houston, Texas, U.S.A.
}

\section{With 7 Text-figures}

\begin{abstract}
The fine structure of the mesogloea of the column of Pachycerianthus fimbriatus MCMuRRICH, a ceriantharian anemone, has been investigated. The mesogloea is bounded by basal laminae. It contains two classes of fibrils. Bundles of fibrils arise opposite projections of the endodermal epithemuscular cells and cross the main mesogloeal layer. In the remainder of the mesogloea individual liomuscular cells and fibrils are embedded in electron lucent material.
\end{abstract}

\section{Introduction}

The presence of fibres with the staining and other properties of collagen in the mesogloea is well established for various coelenterates. This evidence was reviewed by Chapman (1966). One the other hand, the presence of non-collagenous fibres is much more controversial.

Workers using the traditional stains for vertebrate elastin such as orcein, resorcinfuchsin, and aldehyde fuchsin produced conflicting data. ELDER and OWEN (1967) demonstrated that "elastic" fibres were present in a wide range of invertebrates which were distinct from collagen, vertebrate elastic fibres, and reticular fibres. These fibres could be stained by aldehyde fuchsin or spirit blue following oxidation with potassium permanganate. They also were digested by elastase only following treatment with potassium permanganate. These fibrils were found in Lucernaria and Pelagia, scyphozoan medusae, but not in the actinian anemone Calliactis.

Aral (1969) showed that in Pachycerianthus fimbriatus MCMURRICH, a ceriantharian anemone, the main mesogloeal layer of the column wall could be tentatively identified as collagenous by staining with MASSON or VAN GrESON's picrofuchsin stains. However, a thin layer located between the endodermal myonemes and the main mesogloeal layer and fibres extending from this layer across the main mesogloeal layer to the mesogloeal lamellae can be distinguished. Both of these structures stain with aldehyde fuchsin after oxidation with potassium permanganate and with spirit blue but

1) Present address: State University of New York, College at Old Westbury, Nassau, N. Y. 
not with MASSON, VAN GIESON's picrofuchsin, orcein, or WeIGERT's resorcin fuchsin. These data indicate the presence of "elastic" fibres in an anthozoan.

The present paper describes further work on the mesogloea of $P$. fimbriatus particularly on the fine structure with special reference to the fibre characteristics.

\section{Materials and Methods}

Specimens of Pachycerianthus fimbriatus MCMURRICH were obtained from Los Angeles Harbour, California, by the Pacific Bio-Marine Supply Co.

For light microscopy sections of paraffin embedded portions of the column were stained by HeIDENHAIN's iron hematoxylin and eosin, MAsson's trichrome stain modified to include an acid fuchsin-ponceau de xylidine mixture and aniline blue, spirit blue (ELDER and OWEN, 1967) counterstained with VAN Gieson's picro-fuchsin, orcein, WEIGERT's resorcin fuchsin, or GOMORI's aldehyde fuchsin method for elastic fibers as modified by GABE (1953), the last three with and without previous oxidation with potassium permanganate. Details of these procedures were given by ARAI (1969).

For light and electron microscopy following plastic embedding specimens were maintained in sea water tanks at the Department of Biology, Rice University, Houston. On removal animals were anaesthetized for half an hour in equal parts of artificial sea water (Instant Ocean) and a solution of $0.36 \mathrm{M} \mathrm{MgCl}_{2} \cdot 6 \mathrm{H}_{2} \mathrm{O}$. Portions of the column were removed from just below the shortest mesenteries and placed in ice-cold $4 \%$ glutaraldehyde prepared in Instant Ocean, or in KARNOVSKY's solution (KARNOVSKY, 1965) at room temperature. Slices of less than $1 \mathrm{~mm}$ thickness were cut in fixative. Glutaraldehyde fixed tissue was washed overnight in Instant Ocean, post-fixed in $1 \%$ osmic acid in Instant Ocean, and embedded in epoxy resin (mixture $\$ 1$ of MolleNHAUER, 1964). Material fixed in KARNOvSKY's solution was washed overnight in $0.2 \mathrm{M}$ cacodylate buffer, post-fixed in $1 \%$ osmic acid in cacodylate buffer and embedded.

For electron microscopy silver to gray sections were cut on a SORVALL MT-2 microtome. Sections were either examined unstained or following various staining procedures. The latter included: saturated acqueous solution of uranyl acetate mixed with an equal volume of ethanol followed by alkaline lead citrate (VENABLE and CoGGESHALL, 1965); lead citrate only; uranyl acetate only; or $10 \%$ acqueous phosphotungstic acid. Sections were examined on an RCA Emu $3 \mathrm{~F}$ electron microscope. For routine observation by light microscopy approximately $1 \mu$ thick sections were stained

Cross sections of the column of Pachycerianthus fimbriatus.

Fig. 1. Endodermal epitheliomuscle cells and the main mesogloeal layer. Note the basal lamina (B) and collagenous fibrils in the mesogloea. Arrows indicate "elastic" fibres opposite extensions of epitheliomuscle cells. Glutaraldehyde and osmium fixation. Uranyl acetate and lead citrate staining. Magnification 10,000 X.

Fig. 2. Origin of "elastic" fibres (F) opposite bases of epitheliomuscle cells. Note separation of fibres from the cell membrane by the basal lamina. Glutaraldehyde and osmium fixation. Uranyl acetate and lead citrate staining. Magnification 27,500 X. 


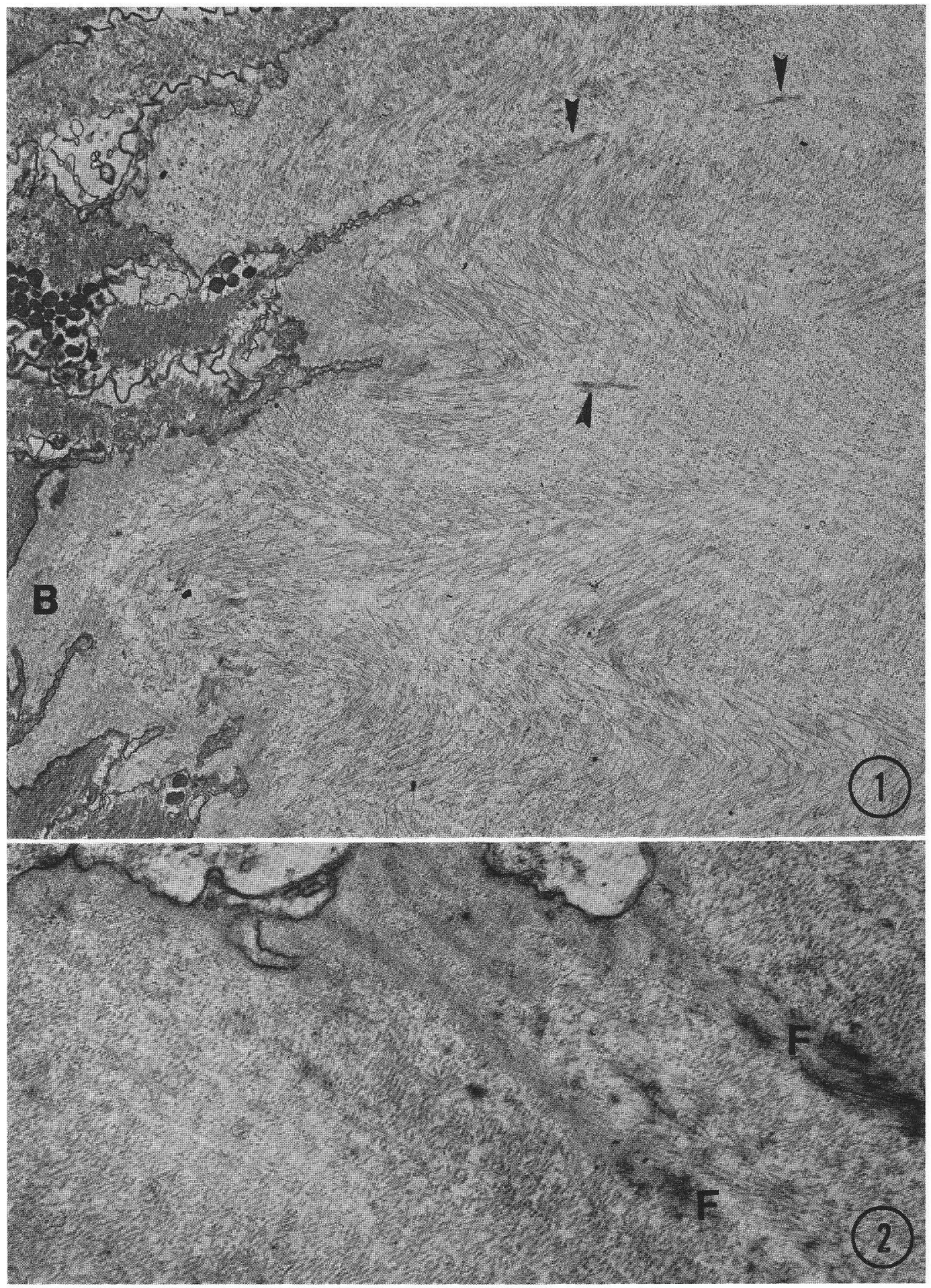




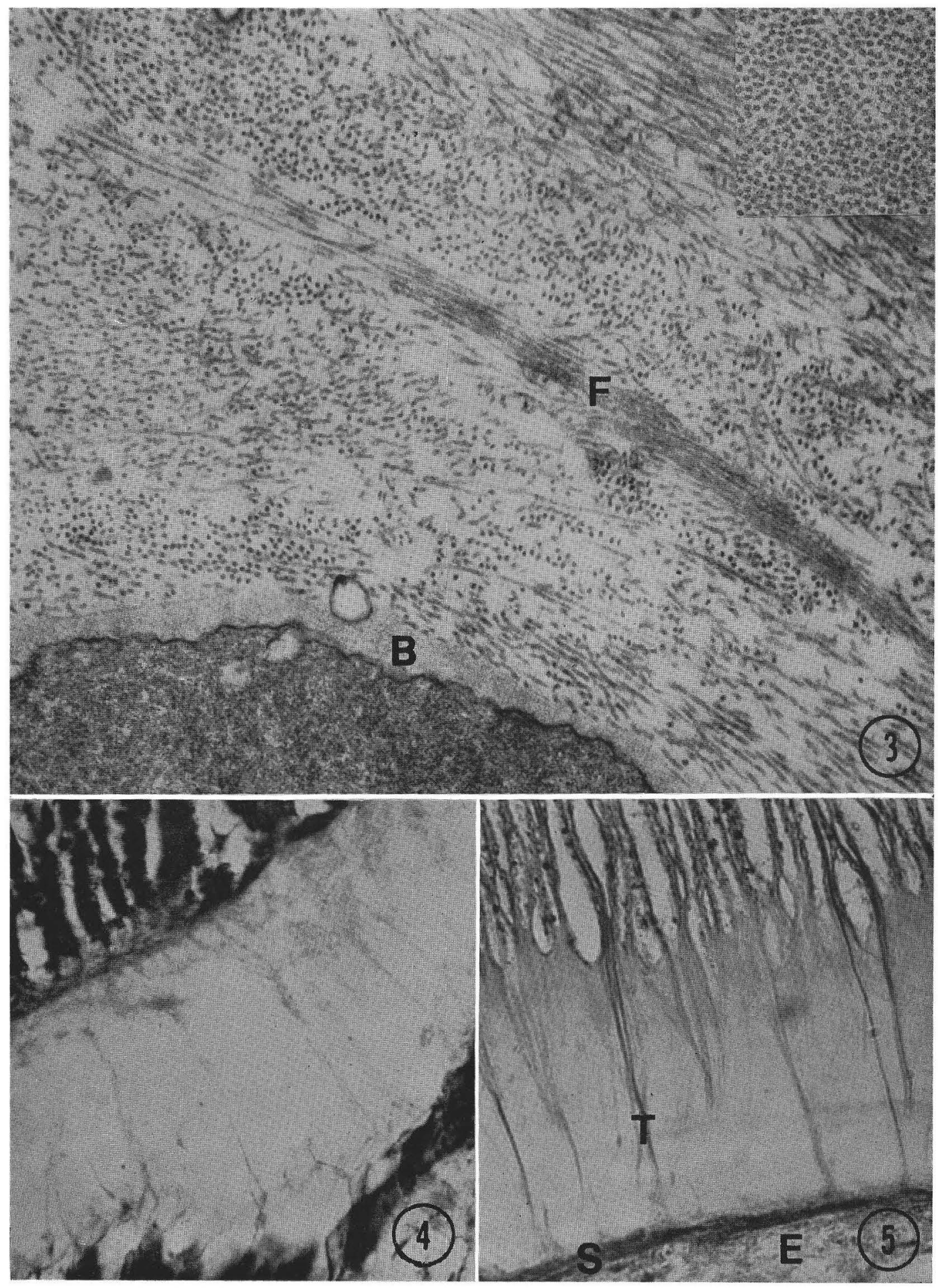



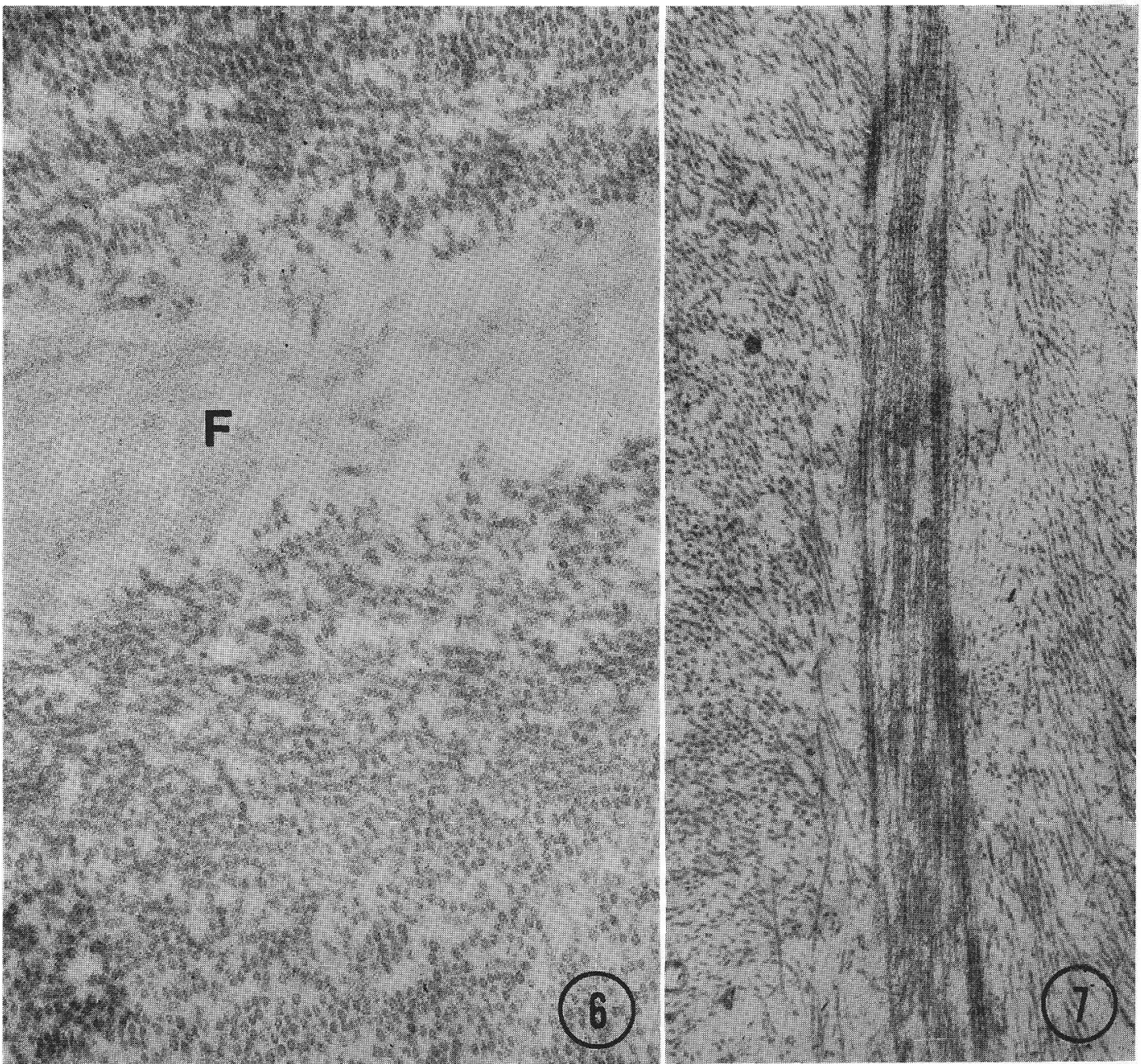

Cross sections of the column of Pachycerianthus fimbriatus.

Fig. 3. Bundle of "elastic" fibrils (f) at the intersection of a radial lamella with the main mesogloeal layer. Note the basal lamina (B) surrounding an ectodermal myoneme. Glutaraldehyde and osmium fixation. Uranyl acetate and lead citrate staining. Magnification 37,500 X.

Fig. 3 (insert). Portion of the main mesogloeal layer to show electron lucent cores of collagenous fibrils. Glutaraldehyde and osmium fixation. Uranyl acetate and lead citrate staining. Magnification $55,000 \mathrm{X}$.

Fig. 4. Cross section of main mesogloeal layer and radial lamellae showing digestion with collagenase. Note a resistant band at the base of the radial lamellae and resistant strands crossing the main mesogloeal layer. Ethanol fixation. Paraffin embedding. MAsson's trichrome stain. Magnification $540 \mathrm{X}$.

Fig. 5. Cross section of main mesogloeal layer and radial lamellae to show the aldehyde fuchsin positive structures identified by light microscopy; a subendodermal layer (S) beneath the endodermal muscle (E) and transverse fibre tracts (T). Picro-formal fixation. Paraffin embedding. Aldehyde fuchsin staining. Magnification $540 \mathrm{X}$.

Fig. 6. Portion of main mesogloeal layer to show electron lucent cores of collagenous fibrils and extremely slight staining of fibrils in an "elastic" fibre (F) by phosphotungstic acid. Glutaraldehyde and osmium fixation. Magnification $62,500 \mathrm{X}$.

Fig. 7. Bundle of elastic fibrils in the main mesogloeal layer. Glutaraldehyde and osmium fixation. Uranyl acetate and lead citrate staining. Magnification 27,500 X. 
with azure II-methylene blue (RiCHARDSON et al., 1960).

Portions of the column were also fixed in $70 \%$ ethanol, embedded in paraffin, and digested with N.B.C. Clostridium histolyticum collagenase or control solutions according to the method of GreEN (1960). They were then stained with MAsson's trichrome stain as modified above.

\section{Results}

As known from previous light microscopy (ARAI, 1969) the mesogloea of the column wall of Pachycerianthus includes a thick layer between the endodermal and ectodermal cell layers and radial lamellae which extend out between, and presumably act as a support for, the longitudinal ectodermal myonemes (see Fig. 5).

Electron microscopy demonstrates (as shown in Figs. 1,2 and 3) that the mesogloea is bounded by basal laminae beneath both the endodermal and ectodermal cells. Fibrils have not been shown in these layers. Light zones separating the basal laminae from the cell membranes are not present.

Between the basement layers are numerous fibrils embedded in electron lucent material. While the arrangement is not completely regular adjacent fibrils tend to run in parallel arrays as shown in Fig. 1. They are of approximately 150 to $230 \AA$ diameter. They possess an electron lucent core following staining with either lead citrate or phosphotungstic acid (Fig. 3 insert and Fig. 6). These fibrils lie in areas of the mesogloea which correspond to areas that stain blue with MASSON's stain and red with VAN GIESON's picrofuchsin stain in paraffin sections (ARAI 1969). This indicates they are probably collagenous. However, we have not been able to clearly discern banding even when the fibrils are intensely stained with phosphotungstic acid.

In addition to these probably collagenous fibrils, bundles of fibrils run across the mesogloeal sheet and enter the mesogloeal lamellae (Figs. 1 and 3). On the endodermal side of the mesogloea these bundles begin opposite projections of endodermal epitheliomuscular cells, from which they are separated by a basal lamina which may itself project into the main mesogleal layer for a short distance (Fig. 2). These fibrils are embedded in amorphous material which is moderately electron dense even in unstained sections. They are stained only very slightly by phosphotungstic acid (Fig. 6) but clearly by uranyl acetate followed by lead citrate (Figs. 3 and 7). These bundles of fibrils correspond in position and approximate number to the "elastic" transverse fibres demonstrated in paraffin sections by staining with aldehyde fuchsin or spirit blue (ARAI, 1969 and Fig. 5). These fibrils are also approximately $150-230 \AA$ in diameter. The fibrils may appear irregularly beaded and cross-linked (Fig. 7).

Although cells are only rarely seen crossing the mesogloea, vesicles are found throughout it. They are bounded by unit membranes and may either appear to be empty or to contain possibly cytoplasmic debris. Small granules may also be present in the interfibrillar matrix. 
Digestion with collagenase (as shown in Fig. 4) removed much of the main mesogloeal layer but left thin strands crossing the area and a band along the ectodermal side of the original layer. The radial lamellae were also still present. Occassionally the thin strands of the main mesogloeal layer appeared coiled in the digested specimens.

\section{Discussion}

This paper includes the first published electron micrographs of coelenterate "elastic" fibres which have also been shown to be spirit blue and aldehyde fuchsin positive at the light microscope level. However, in a preliminary note ELDER (1966) described without illustrations the "elastic" fibres of Haliclystus auricula, a stauromedusa, which appear similar to those in Pachycerianthus. The Haliclystus fibres are composed of fibrils of approximately $150 \AA$ diameter. The fibres often show an indistinct and incomplete cross banding which ELDER suggested may be due to cross bridges between beaded fibrils lying partly in register. He also suggested that the fibrils may be resolved in cross sections into finer sub-units of approximately $30 \AA$ diameter. Unfortunately, fibres in the present study were cut longitudinally or obliquely so this last point cannot be compared.

It is difficult to be sure that coelenterate non-collagenous fibres described by other workers are entirely comparable to the spirit blue positive fibres. There may be a spectrum of fibre types present in coelenterates as in other animal groups. MACKIE and MACKIE (1967) examined fibres from areas of two siphonophores which lacked the $\mathrm{x}$-ray diffraction pattern of collagen. The presumably "elastic" fibre of Nanomia cara, which is shown in a low power electron micrograph in that paper is composed of a bundle of fibrils (MACKIE, personal communication). BOUILLON and VANDERMEERSSCHE (1957) claimed that elastic fibres were present in Limnocnida, Pelagia, and Aurelia but the electron micrographs that they published are of $10,000 \mathrm{X}$ or less magnification, i.e. too small to show any detail which might be present.

Most electron microscopy of fibres of the elastic-like connective tissues has been carried out on vertebrate elastic fibres per se. However, ELDER and OWEN (1967) has investigated the "elastic" fibres of several invertebrates and found them to be composed of bundles of longitudinally oriented fibrils. They suggest that the nearest counterpart in the vertebrates may be the oxytalan fibres or the pre-elastic fibres. Both fibre types, like the invertebrate "elastic" fibres, more closely resemble elastin following oxidation (in staining properties and susceptibility to digestion: see FuLLMER, 1965). CARMiCHAEl and Fullmer (1966) have shown that the oxytalan fibres of the rat periodontal membrane consist of bundles of filaments approximately $150 \AA$ in diameter with an interfilamentous amorphous ground substance.

The fine structure of the vertebrate elastic fibre has been described by HausT and More (1967), Ross (1968), Ross and BorNSTEIN (1969, 1970), and BoDLEY and Wood (1972). It has been found to consist of bundles of microfibrils (approximately 
$100-120 \AA$ in diameter) embedded in or surrounding an amorphous matrix with the chemical properties of isolated elastin. Whereas the fibrils stain with uranyl acetate and lead but the amorphous matrix does not, the matrix stains strongly with phosphotungstic acid but the fibrils do not. In the present study only extremely light staining of the fibrils was obtained with phosphotungstic acid but the electron density of the matrix (already somewhat dense in unstained sections) was not significantly increased either.

It is necessary to consider why the subendodermal layer of mesogloea, as well as the transverse fibrils, is stained by aldehyde fuchsin and spirit blue. At the present level of resolution the basement lamina in this area does not differ significantly from that seen on the ectodermal side. However, it is interesting to speculate that it may contain precursor substances for formation of the "elastic" fibres. This impression is strengthened by the short extensions of the basal lamina into the mesogloeal layer toward the fibres. In vertebrates (see FULLMER, 1965) at the light level aldehyde fuchsin stains pre-elastic as well as elastic fibrils including fine extensions into basement membranes. ELDER and OWEN (1967) state that spirit blue positive fibres may be associated with basement membranes. Membranes similar to basement membranes develop in areas later to be occupied by elastic tissue (Ross, 1971) and HAusT and MORE (1967) note that developing elastic units may be seen "hanging" on the basal membrane by a bridge of substance similar in appearance to the basal membrane.

The non-aggregated fibrils of the general mesogloea have been considered probably collagen or a related protein since these areas stain with MASsON's stain and VAN Greson's picrofuchsin stain in paraffiin sections (ARAI, 1969) and are digested by collagenase. Since HAUSMAN and BURNETT (1969) had found that fibres in Hydra could be broken by both collagenase and elastase it was very pertinent to also investigate the affect of elastase. Unfortunately the necessary buffers were found to be highly disruptive of control sections and no definite conclusions could be drawn from these experiments. Portions of columnar mesogloea from which adhering cells had been scraped were heated slowly and found to contract between 45 and $55^{\circ} \mathrm{C}$. but it is not possible to tell what constituent of the mesogloea was involved in the thermal contractility. Banding of the fibrils has not been seen.

It is possible that the fibrils are too small to display banding. Microfibrils are implicated in the formation of collagen as well as elastic fibres (HAUST and MORE, 1967; Low, 1968; Ross, 1968; FreDERICKSON and Low, 1971). Ross and BENDITT (1961) proposed on the basis of the dimensions of the vertebrate tropocollagen molecule that extracellular collagen of less than $100 \AA$ would not display the characteristic periodicity of $700 \AA$. In practice it is difficult to recognize in fibrils having a diameter less than $200 \AA$. However, a variable periodicity or beading can be recognized on much smaller microfibrils. In coelenterates this minimum diameter may be different if, as indicated by differences presently found in the banding patterns, the collagen is chemically different. Collagen may also vary from coelenterate to coelenterate. 
MACKIE and MACKIE (1967) did not observe periodic banding in the 50-80 $\AA$ diameter collagenous fibrils of Hippopodius. GRIMSTONE et al. (1958) found in the sea anemone Metridium senile that approximately $100 \AA$ diameter fibrils display a banding pattern of $220 \AA$ to $250 \AA$. LEGHISSA and QUAGLIA (1965) found a periodicity of $90 \AA$ to $150 \AA$ in the approximately $150 \AA$ thick fibrils of Actinia equina which are present in bundles. For fibres with much greater diameter BATHAM (1960) found a periodicity of $420 \AA$ to $460 \AA$ in Metridium canum. CHAPMAN (1970) found a banding of $660 \AA$ on the fibrils of Aurelia aurita scyphistoma tentacles. In Hydra DAVIS and HAYNES (1968) and earlier workers found that the presumably collagenous common fibrils of 70 $90 \AA$ are "beaded" at $100 \AA$ but that occasionally fibres of $360-450 \AA$ diameter are present which are clearly banded with a periodicity of $300 \AA$. It is possible that banding would be difficult to discern in the $150 \AA-230 \AA$ fibrils in Pachycerianthus but that negative staining or other improved methods such as the trypsin digestion utilized by CHAPMAN (1970) might demonstrate banding. It is also pertinent in this regard to mention that non-banded collagen is known in Lumbricus i.e. banding is not a diagnostic feature of collagen (RUDALL, 1968).

In vertebrates microfibrils may appear tubular with an electron lucent core. Such a "hollow" appearance was seen in this study. Grimstone et al. (1958) and Leghissa and QUAGLia (1965) also observed it in collagenous fibrils of Metridium and Actinia respectively.

\section{Acknowledgements}

The technical assistence given by Mrs. Jocelyn Lowenthal, Mrs. Edith Catrett and Mr. Gordon WALDER is gratefully appreciated. Portions of this study were supported by a National Research Council of Canada grant to M.N.A., a National Science Foundation grant $\$ G B 7362$ to S. K. and a National Institute of Health grant \$AI-01384 to Dr. C. READ. We are grateful to Dr. C. W. PHILPOTT and Dr. G. O. MACKIE for reading a preliminary draft of the manuscript.

\section{REFERENCES}

AraI, M. N. 1969. "Elastic" fibres in the mesogloea of Pachycerianthus torreyi (Anthozoa). Can. J. Zool, 47: 148-150.

BАтнам, E. J. 1960. The fine structure of epithelium and mesogloea in a sea anemone. Quart. J, Microscop. Sci., 101 : 481-485.

BODLEY, H. D. and WoOD, R. L. 1972. Ultrastructural studies on elastic fibers using enzymatic digestion of thin sections. Anat. Record, 172: 71-88.

Boullon, J. and Vandermeerssche, G. 1957. Structure et nature de la mésoglée des Hydro- et Scyphoméduses. Ann. Soc. Roy. Belgique., 87: 9-25.

Carmichael, G. G. and Fullmer, H. M. 1966. The fine structure of the oxytalan fibre. J. Cell Biol., 28: 33-36.

Chapman, G. 1966. The sturcture and function of the mesogloea. In The Cnidaria and their Evolution. Edited by W. J. Rees. Symp. Zool. Soc. London. No. 16. Academic Press, London.

Chapman, D. M. 1970. Reextension mechanism of a scyphistoma's tentacle. Can. J. Zool. 48: 931943. 
Elder, H. Y. 1966. The fine structure of some invertebrate fibrillar and lamellar elastica. Proc. Roy. Microscop. Soc., 1: 99-100.

Elder, H. Y. and OWen, G. 1967. Occurrence of "elastic" fibres in the invertebrates. J. Zool. London., 152: 1-8.

Davis, L. E. and HAYNES, J. F. 1968. An ultrastructural examination of the mesogloea of Hydra. Z. Zellforsch. Mikroskop. Anat., 92: 149-158.

Frederickson, R. G. and Low, F. N. 1971. The fine structure of perinotochordal microfibrils in control and enzyme-treated chick embryos. Am. J. Anat., $130: 347-376$.

FULLmer, H. M. 1965. The histochemistry of the connective tissues. Intern. Rev. Connective Tissue Res., 3: 1-76.

Gabe, M. 1953. Sur quelques applications de la coloration par la fuchsine-paraldéhyde. Bull. Microscop. Appl., 3: 152-162.

Green, J. A. 1960. Digestion of collagen and reticulin in paraffin sections by collagenase. Stain technol., 35: 273-276.

Grimstone, A. V., Horne, R. W., Pantin, C. F. A., and Robson, E. A. 1958. The fine structure of the mesenteries of the sea-anemone Metridium senile. Quart. J. Microscop. Sci., 99: 523-540.

Hausman, E., and Burnett, A. L. 1969. The mesogloea of Hydra. I Physical and histochemical properties. J. Exp. Zool., 171: 7-14.

HaUST, M. D., and MORE, R. H. 1967. Electron microscopy of connective tissues and elastogenesis. In The Connective Tissue. Edited by B. M. WAGner and D. E. SMITH. Intern. Acad. Pathol. Monograph. Williams and Wilkins Co., Baltimore.

KARNovsKY, M. J. 1965. A formaldehyde-glutaraldehyde fixative of high osmolarity for use in electron microscopy. J. Cell Biol., 27: 137A-138A.

Leghissa, S. and Quaglia, A. 1965. Ricerche submicroscopiche sugli Antozoi. I-Struttara submicroscopica della mesodermide nei tentacoli di Actinia equina. Boll. Zool., 32: 1087-1108.

Low, F. N. 1968. Extracellular connective tissue fibrils in the chick embryo. Anat. Record, 160: 93-108.

MACKIE, G. O. and MACKIE, G. V. 1967. Mesogloeal ultrastructure and reversible opacity in a transparent siphonophore. Vie et Milieu. Ser. A.: Biol. Marine., 18: 47-71.

Mollenhauer, H. H. 1964. Plastic embedding mixtures for use in electron microscopy. Stain Technol., 39: 111-114.

Richardson, K. C., JARETT, L., and FinKE, E. H. 1960. Embedding in epoxy resins for ultra-thin sectioning in electron microscopy. Stain Technol., 35: 313-323.

Ross, R. 1968. The connective tissue fibre forming cell. In Treatise on Collagen Vol. 2. Biology of Collagen, Part A. Edited by B. S. Gould. Academic Press, London.

Ross, R. 1971. The smooth muscle cell II. Growth of smooth muscle in culture and formation of elastic fibres. J. Cell. Biol., 50: 172-186.

Ross, R. and BENDITT, E. P. 1961. Wound healing and collagen formation I. Sequential changes in components of guinea pig skin wound observed in the electron microscope. J. Biophys. Biochem. Cytol., 11: 677-700.

Ross, R. and BoRnsteIn, P. 1969. The elastic fibre I. The separation and partial characterization of its macromolecular components. J. Cell. Biol., 40: 366-381.

Ross, R. and Bornstein, P. 1970. Studies of the components of the elastic fiber. In Chemistry and Molecular Biology of the Intercellular Matrix. Vol. 1. Collagen, Basal Laminae, Elastin. Edited by E. A. Balazs. Academic Press, London.

RuDALL, K. M. 1968. Comparative biology and biochemistry of collagen. In Treatise on Collagen. Vol. 2. Biology of Collagen. Part A. Edited by B. S. Gould. Academic Press, London.

Venable, J. H., and CogGeshall. 1965. A simplified lead citrate stain for use in electron microscopy. J. Cell Biol., 25: 407-408. 


\section{DISCUSSION}

SATo: I would like to know any possible sign of the periodicity of cross bridges which has been shown in between the oriented fibrils.

ARAI, M.: They may appear irregularly cross-linked but no regular periodicity is apparent.

Ross: Can you relate your elastic fibres to the specific cells which produce them?

AraI, M.: It is possible that they are produced by the endodermal epithelio-muscular cells since they extend opposite projections of these cells, but I do not have any direct evidence. The aldehyde fuchsin staining of the subendodermal layer of the mesogloea indicates that precursor substances are probably produced by endodermal cells. 